\title{
In Vitro Regeneration and Genetic Transformation of Cucumis metuliferus through Cotyledon Organogenesis
}

\author{
Yu-Tsung Lin, Chia-Wei Lin, Chien-Hung Chung, and Mei-Hsiu Su \\ Department of Agronomy, National Chung Hsing University, Taichung 40227, \\ Taiwan
}

Hsiu-Yin Ho, Shi-Dong Yeh, and Fuh-Jyh Jan ${ }^{1}$
Department of Plant Pathology, National Chung Hsing University, Taichung
40227, Taiwan

Hsin-Mei Ku

Department of Agronomy, National Chung Hsing University, Taichung 40227, Taiwan

Additional index words. Agrobacterium transformation, $\beta$-glucuronidase, horned melon

\begin{abstract}
This study was undertaken to establish for the first time an efficient regeneration and transformation system for Cucumis metuliferus line PI292190, which is the source of a well-defined resistant gene, $W m v$, that provides resistance against Papaya ringspot virus type P (PRSV-P) and PRSV-W (formerly known as Watermelon mosaic virus 1, WMV-1). Different combinations of growth regulators were evaluated for the regeneration of cotyledon explants. Adventitious buds or shoot primordia were obtained within 3 to 4 weeks on regeneration medium. After shoot development, adventitious buds or shoot primordia were transferred to elongation medium for 3 to 4 weeks and these shoots were subcultured onto rooting medium for another 1 to 2 weeks. Under optimal culture conditions, a total of 7 to 10 weeks was necessary to obtain $C$. metuliferus plantlets from cotyledons. Furthermore, transgenic plants were successfully obtained using an Agrobacterium tumefaciens-mediated transformation method as shown by polymerase chain reaction analysis and histochemical $\beta$-glucuronidase (GUS) assay. A total of nine transgenic plants were developed from 360 cotyledon explants, giving a transformation frequency of $2.5 \%$.
\end{abstract}

Cucumis metuliferus (Naud.) Mey, one of the traditional vegetables originated from South Africa, provides high-quality nutrition sources and is consumed daily as a vegetable by many rural communities in Africa (Kristkova et al., 2003). Its other names include jelly melon, horned melon, or hedgehog gourd, and it is generally marketed as Kiwano. It is an important supplement of fiber and mineral elements, namely potassium, calcium and magnesium (Odhav et al., 2007; Romero-Rodriguez et al., 1992). The novel flavor of $C$. metuliferus fruit may be useful in an innovative tea or beverage. The fruits contain high antioxidant com-

\footnotetext{
Received for publication 10 Nov. 2010. Accepted for publication $11 \mathrm{Feb} .2011$.

This work was supported by a grant from the "Program for promoting academic excellence of universities" from the National Science Council in Taiwan (No. NSC 95-2752-B-005-004-PAE).

We are grateful to Dr. Wen-Hsiung Ko, Professor Emeritus of the University of Hawaii at Manoa; Dr. Chung-Jan Chang, Professor of Plant Pathology at the University of Georgia, Griffin Campus; and Dr. Anne Frary, Professor of Izmir Institute of Technology, Turkey, for their critical review and helpful suggestions of the manuscript.

${ }^{1}$ To whom reprint requests should be addressed; e-mail fjjan@nchu.edu.tw,hmku@nchu.edu.tw.
}

pounds (Breithaupt et al., 2002) and medicinal properties when applied to laboratory rats (Motlhanka, 2008; Wannang et al., 2007). Moreover, C. metuliferus was reportedly able to provide competence for heat and salt tolerance (Benzioni et al., 1991), prolong fruit shelf life (Mendlinger et al., 1992), and increase resistance against Cucurbit yellowing stunting disorder virus (Lopez-Sese and Gomez-Guillamon, 2000), PRSV-P, PRSV-W (formerly known as WMV-1) and Squash mosaic virus (Provvidenti and Gonsalves, 1982; Provvidenti and Robinson, 1974, 1977), whitefly (Lopez-Sese and GomezGuillamon, 2000), fusarium wilt caused by Fusarium oxysporum $\mathrm{f}$. sp. melonis (Nisini et al., 2002), and root-knot nematode (Chen and Adelberg, 2000; Nugent and Dukes, 1997; Siguenza et al., 2005; Wehner et al., 1991).

The previously described regeneration procedures for $C$. metuliferus vary greatly with respect to the genotype of plants, the explant sources, and growth regulators used (Adelberg, 1998; Beharav and Cohen, 1994; McCarthy et al., 2001; Punja et al., 1990; Raharjo and Punja, 1993; Tang and Punja, 1989). The frequency of shoot formation in C. metuliferus PI 292190 from petiole explants was $14.6 \%$ (Raharjo and Punja, 1993); however, 0\% to $30 \%$ from leaf explants and $0 \%$ to $10 \%$ from cotyledon explants were observed (Punja et al., 1990).

In addition, no information on transformation of $C$. metuliferus is available so far, although ample transformation systems for melon, watermelon, squash, muskmelon, and cucumber have been developed by Agrobacterium tumefaciens-mediated transformation (Choi et al., 1994; Fang and Grumet, 1990; Gonsalves et al., 1994; Pang et al., 2000; Vasudevan et al., 2007) or microprojectiles protocols (Chee and Slightom, 1992). It was reported that genotype and growth regulators are determining factors influencing regeneration efficiency in the Cucurbitaceae family (Oridate et al., 1992). 2, 4-dichlorophenoxy-acetic acid (2,4-D) is more frequently used in genotype of Cucurbita species for somatic embryogenesis, yet naphthaleneacetic acid (NAA) is used in Cucumis species. In addition, benzyladenine (BA) was shown to give the best response on shoot production derived from cotyledon explants in Cucumis species (Abrie and van Staden, 2001; Chee, 1991; Niedz et al., 1989) and shoot primordia formation through organogenesis on NAA/BA or NAA/zeatin combinations (Punja et al., 1990).

In this study, a successful organogenic regeneration procedure (with greater than $58 \%$ efficiency) for $C$. metuliferus is described. Meanwhile, two binary vectors, pBI121 (Chen et al., 2003) and TWBI, were used in A. tumefaciens-mediated transformation. A. tumefaciens-mediated delivery of the $\beta$-glucuronidase gene (gus) in C. metuliferus was obtained at a frequency of $2.5 \%$. This is the first report on an efficient regeneration and $A$. tumefaciens-mediated transformation in C. metuliferus.

\section{Materials and Methods}

Plant material and regeneration system. The seedcoats of C. metuliferus line PI 292190 were removed and the naked seeds were surface-disinfected by dipping in $0.5 \%$ sodium hypochlorite for $10 \mathrm{~min}$ followed by three rinses in sterile distilled water. The sterilized seeds were placed on Murashige and Skoog (MS) medium (pH 5.7) including Gamborg B5 vitamins (Duchefa, The Netherlands) for 1 to $2 \mathrm{~d}$. Embryos were removed from sterilized seed and the residual cotyledons were used as explants. Each enlarged cotyledon was longitudinally and transversally dissected to eight equal parts for regeneration. After 3 to 4 weeks on regeneration medium (using various combinations of NAA, BA, and 2,4-D as shown in Table 1), callus, adventitious buds, or shoot primordia derived from cotyledon explants were excised and transferred to elongation medium $\left(0.1 \mathrm{mg} \cdot \mathrm{L}^{-1}\right.$ BA, $\left.0.02 \mathrm{mg} \cdot \mathrm{L}^{-1} \mathrm{NAA}\right)$. After further incubation for 3 to 4 weeks, the elongated shoots were transferred to rooting medium (MS medium containing $0.5 \mathrm{mg} \cdot \mathrm{L}^{-1}$ indole-3-butyric acid) and maintained in a tissue culture room under 16-h light/8-h dark cycles with a photon flux rate of 55 to $65 \mu \mathrm{Em}^{-2} \cdot \mathrm{s}^{-1}$ from cool white fluorescent lamps. The rooted shoots 
were acclimatized in a greenhouse under controlled conditions of $26 \pm 2{ }^{\circ} \mathrm{C}$. All plant growth regulators were filter-sterilized and added into the medium, which had been autoclaved $\left(15 \mathrm{~min}\right.$ at $121{ }^{\circ} \mathrm{C}$ and $\approx 1 \mathrm{kPa}$ ) after $\mathrm{pH}$ adjustment ( $\mathrm{pH}$ 5.7). Approximately $15 \mathrm{~mL}$ of medium was dispensed into disposable petri dishes $(90 \times 20 \mathrm{~mm})$ for regeneration and elongation and $30 \mathrm{~mL}$ of rooting medium was dispensed into Magenta GA7 vessels for rooting.

Selection of kanamycin and DLphosphinothricin. To determine the appropriate concentration of kanamycin and DL-phosphinothricin (PPT) for selection of transgenic explants, Agrobacterium-infected cotyledon explants were placed on S1 medium (MS medium supplemented with $1.0 \mathrm{mg} \cdot \mathrm{L}^{-1}$ BA and $0.02 \mathrm{mg} \cdot \mathrm{L}^{-1} \mathrm{NAA}$ ) containing different concentration of kanamycin or PPT (Table 2). Surviving explants with adventitious buds or shoot primordia were excised and transferred to S2 medium (MS medium supplemented with $0.1 \mathrm{mg} \cdot \mathrm{L}^{-1} \mathrm{BA}, 0.02 \mathrm{mg} \cdot \mathrm{L}^{-1}$ NAA) under the same selection conditions. The number of surviving shoots was recorded after 2 weeks. The concentration of kanamycin or PPT that gave the highest frequency of shoot development was chosen as the criterion for the transformation of $C$. metuliferus.

Table 1. The effect of auxins (NAA, 2,4-D) and cytokinin (BA) concentration on regeneration of buds or shoot primordia derived from Cucumis metuliferus cotyledon explants.

\begin{tabular}{|c|c|c|c|c|}
\hline \multicolumn{3}{|c|}{ Concn of growth regulator $\left(\mathrm{mg} \cdot \mathrm{L}^{-1}\right)$} & \multirow{2}{*}{$\begin{array}{c}\text { Number of } \\
\text { cotyledon explants }\end{array}$} & \multirow{2}{*}{$\begin{array}{c}\text { Number of calli (-C), } \\
\text { buds (-B), or shoot } \\
\text { primordia (-SP) (frequency) }\end{array}$} \\
\hline $\mathrm{BA}$ & NAA & $2,4-\mathrm{D}$ & & \\
\hline 0.5 & 0.02 & & 48 & $27-\mathrm{C}(27 \%), 20-\mathrm{B}(20 \%), 15-\mathrm{SP}(31.3 \%)$ \\
\hline 1.0 & 0.02 & & 48 & $40-\mathrm{C}(40 \%), 29-\mathrm{B}(29 \%), 20-\mathrm{SP}(41.7 \%)$ \\
\hline \multirow[t]{6}{*}{1.0} & & & 48 & $23-\mathrm{C}(23 \%), 19-\mathrm{B}(39.6 \%), 8-\mathrm{SP}(16.7 \%)$ \\
\hline & 0.02 & 0.2 & 160 & $160-\mathrm{C}(100 \%), 7-\mathrm{B}(4.4 \%)$ \\
\hline & 0.02 & 0.5 & 160 & $160-\mathrm{C}(100 \%)$ \\
\hline & 0.02 & 1.0 & 160 & $160-\mathrm{C}(100 \%)$ \\
\hline & 0.2 & & 50 & $36-\mathrm{B}(72 \%)$ \\
\hline & 0.5 & & 50 & $37-\mathrm{B}(74 \%)$ \\
\hline
\end{tabular}

${ }^{2}$ The frequency was calculated by using the number of calli (-C), buds (-B), or shoot primordia (-SP) divided by the number of cotyledon explants in each experiment.

$\mathrm{NAA}=$ naphthaleneacetic acid; 2,4-D = 2, 4-dichlorophenoxy-acetic acid; $\mathrm{BA}=$ benzyladenine .

Table 2. Effect of kanamycin and DL-phosphinothricin (PPT) concentration on regeneration of buds or shoot primordia from Agrobacterium-inoculated Cucumis metuliferus cotyledon explants.

\begin{tabular}{|c|c|c|c|c|}
\hline \multicolumn{2}{|c|}{ Concn of selective agent } & \multirow{2}{*}{$\begin{array}{l}\text { Number of } \\
\text { cotyledon } \\
\text { explants }\end{array}$} & \multirow{2}{*}{$\begin{array}{c}\text { Number (frequency) } \\
\text { of surviving cotyledon } \\
\text { explants }^{z}\end{array}$} & \multirow{2}{*}{$\begin{array}{l}\text { Number of calli }(-C) \text {, buds } \\
\text { (-B), or shoot primordia } \\
\text { (-SP) (frequency) }\end{array}$} \\
\hline $\begin{array}{l}\text { Kanamycin } \\
\left(\mathrm{mg} \cdot \mathrm{L}^{-1}\right)\end{array}$ & $\begin{array}{c}\text { PPT } \\
\left(\mathrm{mg} \cdot \mathrm{L}^{-1}\right)\end{array}$ & & & \\
\hline 50 & & 333 & $177(62.1 \%)$ & $\begin{array}{c}1-\mathrm{C}(0.6 \%), 40-\mathrm{B}(22.6 \%) \\
13-\mathrm{SP}(7.3 \%)\end{array}$ \\
\hline 150 & & 379 & $341(89.9 \%)$ & $\begin{array}{l}52-\mathrm{B}(15.2 \%), 52-\mathrm{SP} \\
\quad(15.2 \%)\end{array}$ \\
\hline \multirow[t]{8}{*}{200} & & 433 & $301(78.1 \%)$ & $30-\mathrm{B}(10 \%), 6-\mathrm{SP}(2 \%)$ \\
\hline & 33.8 & 200 & $63(31.5 \%)$ & 0 \\
\hline & 22.5 & 171 & $68(39.7 \%)$ & $1-\mathrm{B}(1.5 \%)$ \\
\hline & 16.9 & 267 & $223(83.5 \%)$ & $19-\mathrm{B}(8.5 \%)$ \\
\hline & 13.5 & 545 & $410(75.2 \%)$ & $\begin{array}{l}\text { 44-B }(10.7 \%), 12-\mathrm{SP} \\
\quad(2.9 \%)\end{array}$ \\
\hline & 11.3 & 170 & $101(59.4 \%)$ & 0 \\
\hline & 2.7 & 261 & $93(35.6 \%)$ & $\begin{array}{l}\text { 21-B (22.6\%), 21-SP } \\
(22.6 \%)\end{array}$ \\
\hline & 1.0 & 268 & $155(57.8 \%)$ & $\begin{array}{l}31-\mathrm{B}(24 \%), 24-\mathrm{SP} \\
\quad(15.5 \%)\end{array}$ \\
\hline
\end{tabular}

${ }^{\mathrm{z}}$ Cotyledon explants surviving on regeneration medium containing kanamycin or PPT at different concentrations after 2 weeks.

${ }^{y}$ The frequency was calculated with the number of calli (-C), buds (-B), or shoot primordia (-SP) divided by the number of surviving cotyledon explants, respectively. with $150 \mathrm{mg} \cdot \mathrm{L}^{-1} \mathrm{kanamycin}$ and $250 \mathrm{mg} \cdot \mathrm{L}^{-1}$ carbenicillin) media and subcultured weekly for another 3 to 4 weeks. The number of adventitious buds and shoot primordia formed at the apical site of cotyledon explants were recorded in TS2 medium for a period of 3 to 4 weeks. The rooting procedure (on rooting medium supplemented with $250 \mathrm{mg} \cdot \mathrm{L}^{-1}$ carbenicillin) and acclimation of transformants were the same as described for regeneration experiments. Acclimatized plants were analyzed for transgene by polymerase chain reaction (PCR) and GUS assays.

Detection of transgenes. Plant genomic DNA was extracted from leaves of transgenic plants by a modified CTAB method (Fulton et al., 1995). Forty nanograms of plant genomic DNA was used for PCR analysis performed with denaturing at $94{ }^{\circ} \mathrm{C}$ for $1 \mathrm{~min}$, annealing at $55{ }^{\circ} \mathrm{C}$ for $1 \mathrm{~min}$, and extension at $72{ }^{\circ} \mathrm{C}$ for $2 \mathrm{~min}$ for 30 cycles and a final extension at $72{ }^{\circ} \mathrm{C}$ for $5 \mathrm{~min}$. PCR analysis for the $n p t \mathrm{II}$ gene was performed using primers FJJ2002-14 (5'-CCCCTCGGTATCCAATT AGAG-3') and FJJ2002-15 (5'-CGGGGGGT GGGCGAAGAACTCCAG-3') (Fig. 1A). PCR analysis of the gus gene was performed using primers FJJ1999-12 (5'-ATATGGA TATCTCCACTGACGTAAGGGATG-3') located in the CaMV 35S promoter region and FJJ2001-15 (5'-TGATAATCATCGC AAGAC-3') covering the nos terminator region (Fig. 1A). Southern blot analysis was performed to confirm the integration of the gus gene in the transformants that gave positive PCR results for both transgenes (nptII and gus genes). Vector DNA (as positive control) and genomic DNA of transformed and non-transformed plants were digested by $S c a \mathrm{I}$ and $\mathrm{XhoI}$, electrophoresised in $1 \%$ agarose gels, and blotted onto nylon membranes. The membranes were hybridized with a $\mathrm{P}^{32}$-labeled probe of a $2.0 \mathrm{~kb}$ gus gene fragment, which was PCR amplified from plasmid template with primers FJJ1999-12 and FJJ2001-15. In addition, a histochemical assay to detect GUS activity was performed as described by Jefferson (1987). Leaf tissues were immersed in the reaction buffer $(100 \mathrm{mM}$ Tris, $50 \mathrm{mM}$ $\mathrm{NaCl}$, and $0.1 \%$ Triton-X 100, $\mathrm{pH} 7.0$ ) containing $2 \mathrm{mM}$ potassium ferricyanide and 2 mм 5-bromo-4-chloro-3-indolyl glucuronide (X-gluc) as substrates. The reaction was performed under a mild vacuum for $1 \mathrm{~min}$ after incubation at $37{ }^{\circ} \mathrm{C}$ for 1 to 2 weeks. The tissues were washed with $70 \%$ ethanol before observation. The efficiency of transformation was calculated by dividing the number of PCR-positive plants for both $n p t \mathrm{II}$ and $g u s$ genes by the total number of explants used in three independent experiments.

\section{Results}

Regeneration of cotyledon explants. Some friable, white or pale yellow calli were observed on the medium containing auxin only (NAA and 2,4-D), whereas buds or shoot primordia were observed after adding BA at a concentration of 0.5 or $1.0 \mathrm{mg} \cdot \mathrm{L}^{-1}$ (Table 1). Generally, cotyledon explants enlarged 
considerably and developed into mature callus, buds, or shoot primordia on the margins within 3 weeks after being transferred into regeneration medium (Fig. $2 \mathrm{~A})$. When the mature globular calli were transferred to elongation medium, the regenerated calli failed to form shoots. However, most adventitious buds or shoot primordia were observed
(A)

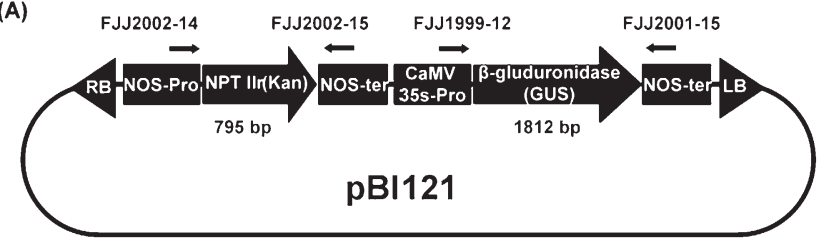

(B)

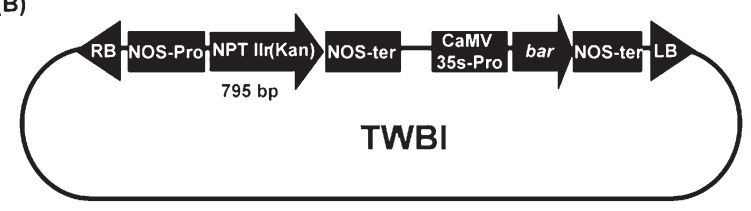

Fig. 1. Schematic diagram of the T-DNA region of the binary plasmids pBI121 (A) and TWBI (B). (A) The Ti plasmid contains neomycin phosphotransferase II (nptII) and $\beta$-gluduronidase (GUS) reporter genes. These two genes were separately fused under the control of the nopaline synthase (NOS-pro) and CaMV 35S promoters (CaMV 35S-pro), respectively. (B) The bar gene conferring resistance to the herbicide Basta is driven by the CaMV $35 \mathrm{~S}$ promoter and the NOS terminator (NOS-ter). RB represents the right border and LB is the left border of the T-DNA.
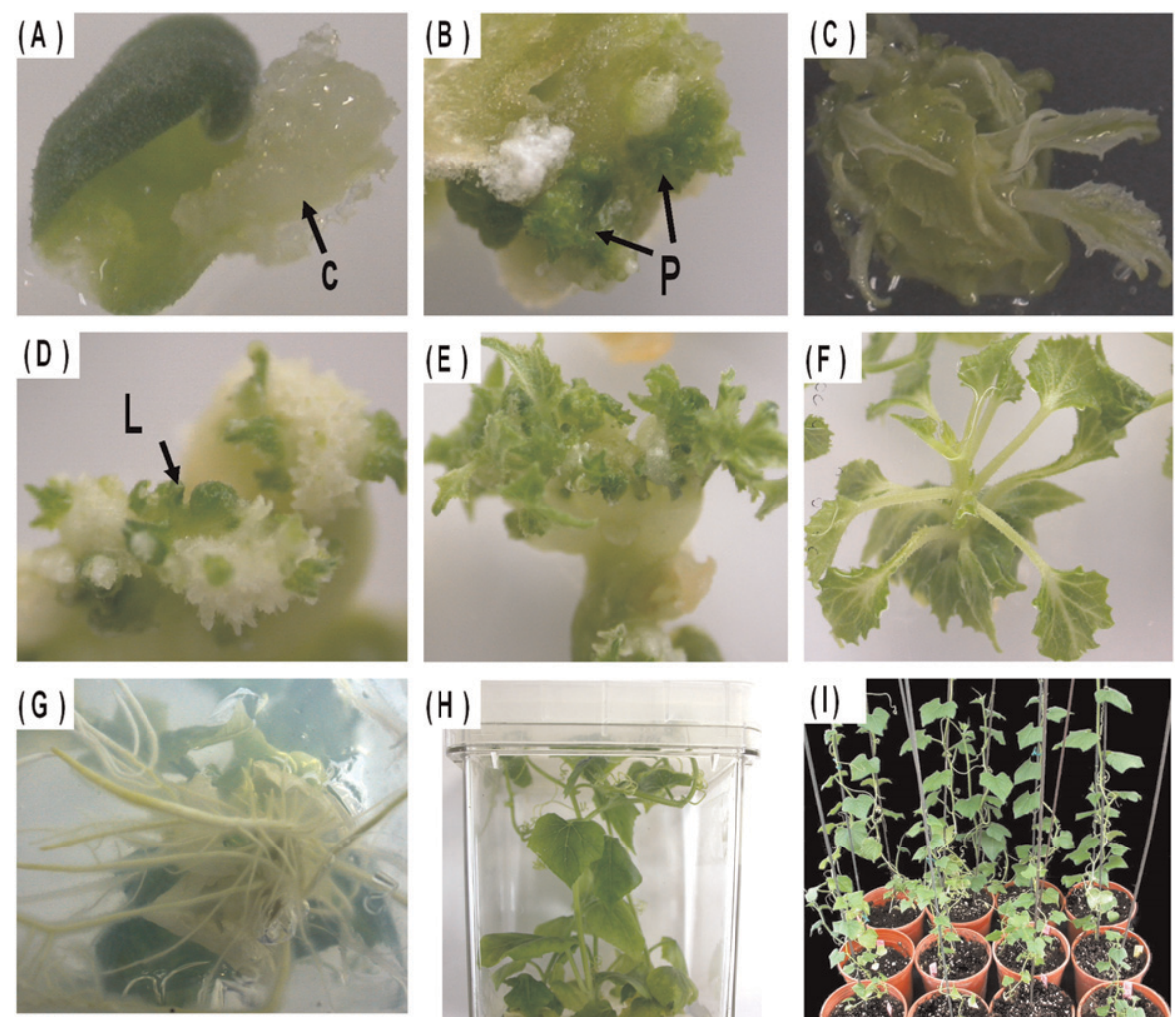

(H)
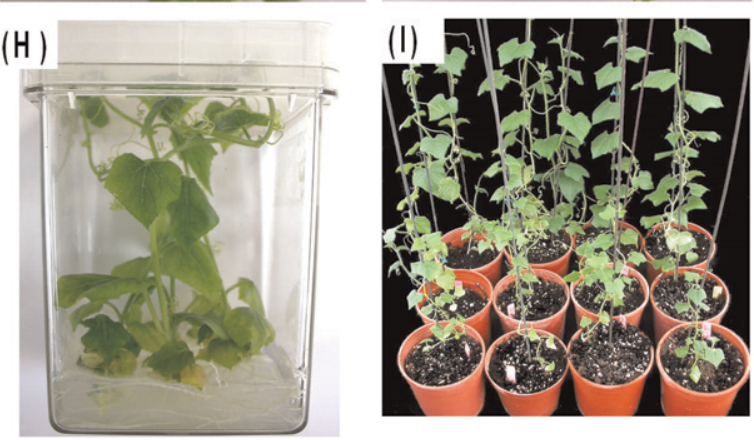

Fig. 2. Plant regeneration and transformation of Cucumis metuliferus line PI 292190. (A) Formation of callus at the cut surface of the cotyledon explants on medium containing $0.02 \mathrm{mg} \cdot \mathrm{L}^{-1} \mathrm{NAA}$ and 0.2 $\mathrm{mg} \cdot \mathrm{L}^{-1} 2,4-\mathrm{D}$ after 3 weeks of culture ( $\mathrm{C}=$ callus). (B) Adventitious shoots formation at the proximal end of the cotyledon in regeneration medium $\left(0.02 \mathrm{mg} \cdot \mathrm{L}^{-1} \mathrm{NAA}\right.$ and $\left.1.0 \mathrm{mg} \cdot \mathrm{L}^{-1} \mathrm{BA}\right)$ after 3 weeks of culture ( $\mathrm{P}=$ protuberance $)$. (C) Adventitious buds showing shoot clustering and severe hyperhydricity after several subcultures. (D-E) Explants showing differentiation into a leaf without the formation of buds or shoot primordia. Formation of abnormal leaves that did not elongate ( $\mathrm{L}=$ leaf-like structure). (F) Healthy plantlets growing in elongation medium. $(\mathbf{G}-\mathbf{H})$ Healthy roots generated in transgenic $C$. metuliferus plantlet obtained after 1 to 2 weeks culturing in the rooting medium. (I) Acclimatized putative transgenic plants. NAA = naphthaleneacetic acid; 2,4-D = 2, 4-dichlorophenoxy-acetic acid; $\mathrm{BA}=$ benzyladenine.

preferentially at the proximal cotyledons (Fig. 2B). When transferred to elongation medium, these buds and shoot primordia continued to grow and formed mature shoots after 3 to 4 weeks. In some cases, cotyledon explants proliferated profusely and formed clusters of shoot apices, which did not develop into normal shoots on elongation medium (Fig. 2C). Some explants directly developed into leaf-like structures without forming buds or shoot primordia (Fig. 2D). In terms of bud or shoot formation, the medium containing $0.02 \mathrm{mg} \cdot \mathrm{L}^{-1} \mathrm{NAA}$ and $1.0 \mathrm{mg} \cdot \mathrm{L}^{-1} \mathrm{BA}$ provided a suitable development. In most cases, buds or shoot primordia developed into normal shoots and leaves (Fig. 2E-F). All elongated shoots were transferred to rooting medium for 1 to 2 weeks (Fig. 2G-H). The plantlets were acclimatized in the greenhouse (Fig. 2I) with the survival rate greater than $95 \%$.

Sensitivity of cotyledons to kanamycin and DL-phosphinothricin. To test the optimal concentrations of kanamycin and PPT for transformation, Agrobacterium-infected cotyledon explants were placed on the selection medium supplemented with various concentrations of kanamycin or PPT (Table 2). After 3 weeks on selection medium, the survival rate of cotyledon explants were $62.1 \%, 89.9 \%$, and $78.1 \%$ when kanamycin was supplemented at 50, 150, and $200 \mathrm{mg} \cdot \mathrm{L}^{-1}$, respectively. Fifty-two buds and 52 shoot primordia were obtained from 341 surviving explants when kanamycin was supplemented at 150 $\mathrm{mg} \cdot \mathrm{L}^{-1}$, whereas fewer buds or shoot primordia were obtained at 50 or $200 \mathrm{mg} \cdot \mathrm{L}^{-1}$ (Table 2). For PPT selection, most cotyledon explants became pale yellowish or developed partial necrosis 3 weeks after being transferred to media supplemented with various concentrations of PPT from 1.0 to $33.8 \mathrm{mg} \cdot \mathrm{L}^{-1}$. The survival rates varied from $31.5 \%$ at 33.8 $\mathrm{mg} \cdot \mathrm{L}^{-1}$ of PPT to $83.5 \%$ at $16.9 \mathrm{mg} \cdot \mathrm{L}^{-1}$ of PPT (Table 2). Although it is cheaper and easier to screen out nontransformants by using PPT than kanamycin, more restriction on buds and shoot primordia development was noticed on PPT selective medium. Therefore, kanamycin at a concentration of $150 \mathrm{mg} \cdot \mathrm{L}^{-1}$ was used for further establishment of C. metuliferus transformation.

Transformation of Cucumis metuliferus. The frequency of buds or shoot differentiation of inoculated explants varied from $43.3 \%$ to $68.3 \%$ in three independent experiments (Table 3). Explants with buds or shoot primordia were dissected and subcultured weekly in TS2 medium for 3 to 4 weeks. Most buds or shoots elongated but some did not develop into normal shoots. These abnormal shoots were hyperhydric and formed unexpanded leaf structures. In contrast, the elongated shoots showed various developments, including no root formation, short root formation, and formation of a strong and branched root system in rooting medium. From these experiments, a total of 53 putative transgenic plantlets was successfully developed with healthy root systems. All of them were acclimatized in the greenhouse (Fig. 2I). 
Detection of the presence of transgenes. DNA isolated from the upper leaves of transformants, untransformed $C$. metuliferus or the pBI121 plasmid was used as template DNA for PCR analysis of transgenes. The presence of a 1.2-kb fragment corresponding to the expected size of the $n p t \mathrm{II}$ gene was detected in transformants and pBI121 plasmid but not in the untransformed $C$. metuliferus (Fig. 3A). A fragment of $2.0 \mathrm{~kb}$ for the gus gene was found in transfomants and pBI121 but not in untransformed C. metuliferus (Fig. 3B). A total of 21 plants were positive in PCR analysis of the $n p t$ II gene but only nine of those plants were also positive for the gus gene. Furthermore, the results of Southern blot analysis showed the presence of the gus gene in the transformants and positive control but not in the untransformed control (Fig. 4). Finally, a GUS expression assay was conducted in transformants showing positive PCR reaction for the gus gene and non-transgenic $C$. metuliferus as a negative control. GUS activity was detected in transformed shoots (Fig. 5A) along the margins of leaves in transgenic plant (Fig. 5B) but not in the non-transgenic control (Fig. 5C) after incubation at $37^{\circ} \mathrm{C}$ for $2 \mathrm{~d}$. Based on the results of PCR analysis and GUS assay, the transformation frequency of $C$. metuliferus was measured to $2.5 \%$ (Table 3 ).

\section{Discussion}

An efficient regeneration system (greater than $58 \%$ ) was obtained for $C$. metuliferus after $A$. tumefaciens infection and the adventitious buds and shoot primordia developed within 3 to 4 weeks. The buds and shoot primordia were cultured on elongation medium for 3 to 4 weeks and finally on rooting medium for another 1 to 2 weeks. A total of 7 to 10 weeks were needed to obtain transformants. An average transformation rate of $2.5 \%$ was achieved; however, a rate as high as $24.2 \%$ was obtained in one of the experiments (Table 3).

In this study, cotyledons were chosen as the explant source to establish an efficient regeneration and transformation system for C. metuliferus line PI 292190. Direct organogenesis from cotyledons offers the following advantages: the easier availability of cotyledon, the avoidance of somatic mutations that may be associated with callus, and it is technically easy and rapid (Vasudevan et al., 2007). It has been widely applied for in vitro regeneration of different genotypes of C. melo (Adelberg et al., 1994; Dong et al., 1991; Ezura et al., 2000; Ficcadenti and Rotino, 1995; Gaba et al., 1999; Galperin et al., 2003; Gonsalves et al., 1994; Molina and Nuez, 1995), C. sativus (Vasudevan et al., 2007; Vengadesan et al., 2005), Cucurbita pepo (Kathiravan et al., 2006), Citrullus lanatus (Chaturvedi and Bhatnagar, 2001), and $C$. metuliferus line PI 482439 (Adelberg, 1998). It was reported that the proximal edges of cotyledon explants conferred the highest regenerability in C. melo (Gaba et al., 1999; Gonsalves et al., 1994). In this study, it was
Table 3. Transformation frequency of Cucumis metuliferus. ${ }^{\mathrm{z}}$

\begin{tabular}{lccccc}
\hline Expt. & $\begin{array}{c}\text { Number of } \\
\text { cotyledon explants } \\
\text { inoculated }\end{array}$ & $\begin{array}{c}\text { Number (frequency) } \\
\text { of adventitious buds } \\
\text { or shoot primordia }^{y}\end{array}$ & $\begin{array}{c}\text { Number } \\
\text { (frequency) of shoot } \\
\text { differentiation }^{\mathrm{x}}\end{array}$ & $\begin{array}{c}\text { Number of } \\
\text { rooted } \\
\text { plantlets }\end{array}$ & $\begin{array}{c}\text { Number } \\
\text { (frequency) } \\
\text { of TP }^{\mathrm{w}}\end{array}$ \\
\hline 1 & 120 & $52(43.3 \%)$ & $36(30.0 \%)$ & 2 & 0 \\
2 & 120 & $82(68.3 \%)$ & $43(35.8 \%)$ & 14 & $10(11.6 \%)$ \\
3 & 120 & $75(62.5 \%)$ & $55(45.8 \%)$ & 37 & $17(24.2 \%)$ \\
Total & 360 & $209(58.0 \%)$ & $134(37.2 \%)$ & 53 & $9(2.5 \%)$ \\
SE & & 12.8 & 7.8 & 14.5 & \\
\hline
\end{tabular}

${ }^{2}$ Precultured cotyledon explants were inoculated with Agrobacterium tumefaciens strain LBA4404 harboring the binary vector pBI121.

${ }^{y}$ Buds or shoot primordia differentiation was recorded after 2 to 3 weeks of culture on TS1 medium. The frequency was calculated by using the number of adventitious buds or shoot primordia divided by the number of cotyledon explants inoculated in each experiment.

${ }^{x}$ Only elongated adventitious buds or shoot primordia were counted. The frequency was calculated by using the number of shoot differentiation divided by the number of cotyledon explants inoculated in each experiment.

${ }^{\text {w }} \mathrm{TP}=$ transgenic plants that were polymerase chain reaction (PCR)-positive in the detection of $n p t \mathrm{II}$ and gus gene. Frequency was calculated by using total number of PCR-positive plantlets divided by the total number of cotyledon explants.

${ }^{v}$ The putative transgenic plants died after acclimatizing in the greenhouse and were not subject to PCR analysis.

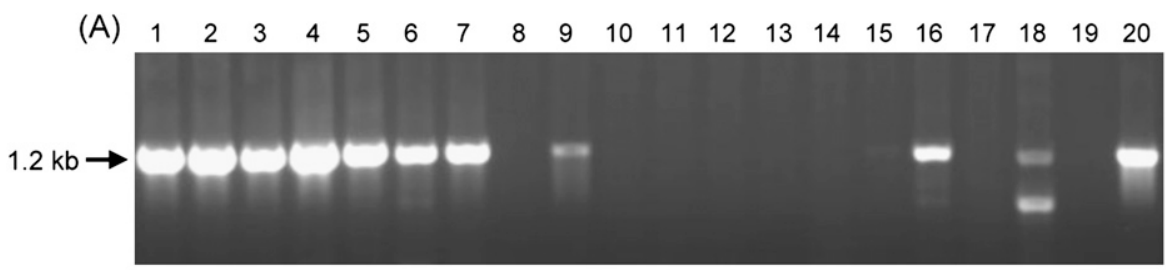

(B)

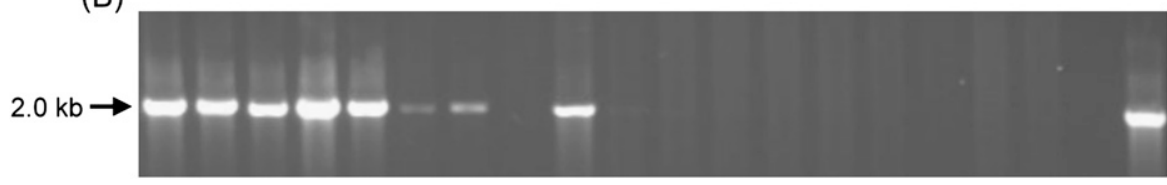

Fig. 3. Polymerase chain reaction (PCR) analysis of $n p t I I$ and $\beta$-glucuronidase genes. PCR amplified fragments of (A) nptII gene and (B) $\beta$-glucuronidase (gus) gene from putative transgenic Cucumis metuliferus (Lanes 1 to 18), non-transgenic Cucumis metuliferus PI 292190 (Lane 19), and plasmid pBI121 (Lane 20). The expected fragment sizes of $1.2 \mathrm{~kb}$ for the $n p t I I$ gene and $2.0 \mathrm{~kb}$ for the gus gene were obtained. Two sets of primers were used for $n p t I I$ and gus PCR detection. The primers FJJ2002-14 and FJJ2002-15 were designed for $n p t I I$ detection and a 1.2-kb fragment was amplified. A $2.0-\mathrm{kb}$ fragment was amplified for gus detection using primers FJJ1999-12 and FJJ2001-15.

also observed that proximal edges of cotyledon explants produced more buds and shoot primordia (Fig. 2B). Normal adventitious buds or shoot primordia were successfully regenerated at a frequency of $58 \%$ from cotyledon explants and from which the frequency of shoot formation reached $37.2 \%$ (Table 3). It was suggested that a higher concentration of NAA $\left(0.37 \mathrm{mg} \cdot \mathrm{L}^{-1}\right)$ or a lower concentration of $2,4-\mathrm{D}\left(0.11 \mathrm{mg} \cdot \mathrm{L}^{-1}\right)$ in combination with $0.22 \mathrm{mg} \cdot \mathrm{L}^{-1} \mathrm{BA}$ can hinder the formation of callus from explants in $C$. metuliferus line PI 292190 (Raharjo and Punja, 1993). In this study, we observed callus regeneration in medium containing $0.02 \mathrm{mg} \cdot \mathrm{L}^{-1}$ NAA and 0.2 to $0.5 \mathrm{mg} \cdot \mathrm{L}^{-1} 2,4-\mathrm{D}$ but this callus failed to regenerate shoots (Fig. 2A). The enhancement of shoot development using higher concentrations of BA in regeneration medium has been reported for five different selected cucurbit cultivars (Abrie and van Staden, 2001). In a study conducted by Gaba et al. (1999), the regeneration of Cucumis species from epidermis and the subepidermal layer was principally derived

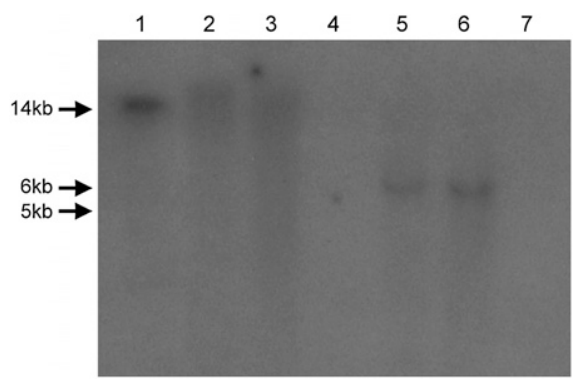
probe derived from a fragment of the gus gene. Lane 1, positive control (vector pBI121 digested by $S c a \mathrm{I}$ ); Lanes 2 and 5, transformants 960822-5; Lanes 3 and 6, transformants 960822-17; Lanes 4 and 7, untransformed negative control (Cucumis metuliferus line PI 292190). Genomic DNA of Lanes 2 to 4 and 5 to 7 plants was digested by ScaI and XhoI, respectively.

from the adaxial surface of cotyledon explants when BA concentrations ranging from 0.22 to $2.2 \mathrm{mg} \cdot \mathrm{L}^{-1}$ were used in the culture medium. In this study, $0.02 \mathrm{mg} \cdot \mathrm{L}^{-1} \mathrm{NAA}$
Fig. 4. Southern blot analysis using $\alpha-{ }^{32} \mathrm{P}$ labeled 

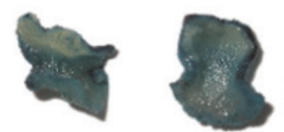

(B)
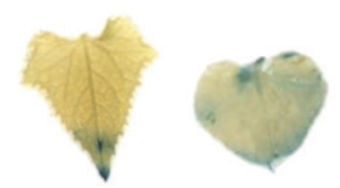

(C)

Fig. 5. Histochemical localization of $\beta$-glucuronidase gene (GUS) expression. The transformed explants (A), leaves of transgenic plants (B) and non-transgenic control, Cucumis metuliferus line PI 292190 (C) were analyzed for 2,4-dichlorophenoxyacetic acid (GUS) staining.

combined with $1.0 \mathrm{mg} \cdot \mathrm{L}^{-1}$ BA were used in regeneration medium for cotyledon explants and from which adequate buds or shoot primordia were regenerated and later developed into normal shoots. However, some explants in this study were found to produce many buds but only few shoots (Fig. 2C). A similar phenomenon has also been reported in regeneration studies of other cucurbits (ColijnHooymans et al., 1994; Compton and Gray, 1993). Gonsalves et al. (1994) reported that buds developing from the epidermis or subepidermal layer, especially those located at the cut part of the cotyledon proximal to the seed apex, and the first organogenesic meristems formed in vitro inhibited the development of further buds. It was suggested that excising the larger shoots permits more buds to develop further (Gaba et al., 1999).

The phenomenon of "escape" from antibiotic selection in the transformation of $C$. melo was reported by Akasaka-Kennedy et al. (2004). In previous work, cotyledon explants under 75 to $100 \mathrm{mg} \cdot \mathrm{L}^{-1}$ kanamycin selection regenerated at frequencies of $15 \%$ for $C$. sativus (Vengadesan et al., 2005), 30\% for muskmelon (Fang and Grumet, 1990), and $75 \%$ to $90 \%$ for melon (Dong et al., 1991). A high proportion of escapes was encountered in cucumber when embryo suspension culture was used under kanamycin selection (Schulze et al., 1995). The occurrence of the escapes may be the result of inadequate selective pressure or cross-protection by secreted products of contaminating microbial cells (Dong et al., 1991). Therefore, it is important to establish an efficient selection for the transformation system, especially for systems using regeneration through direct organogenesis from cotyledon explants (Gaba et al., 1999). In this study, although a high concentration of kanamycin $\left(150 \mathrm{mg} \cdot \mathrm{L}^{-1}\right)$ was used, the occurrence of escape was difficult to avoid completely. As shown in Table 3, an average of $58 \%$ of the Agrobacterium-infected cotyledon explants formed multiple shoots on selective media. However, only nine of 53 putative transgenic lines were detected to contain both $n p t \mathrm{II}$ and gus genes in PCR analysis, indicating a certain degree of escape or chimeric plants regenerated from $C$. metuliferus
PI 292190. It has been postulated that the phenomenon of cross-protection against kanamycin occurred in melon or other Cucumis species and that transformation rate of inoculated melon on selection media is higher than on non-selective media (Dong et al., 1991). Therefore, increasing the selection pressure enables the transformed cells to compete with the non-transformed cells more effectively resulting in a slight decrease in the level of escapes and chimeric plants. Other selection agents such as methotrexate or PPT were also used for efficient selection of transgenic plants in melon and cucumber transformation (Dong et al., 1991; Vengadesan et al., 2005). However, we observed a lower surviving frequency of cotyledon explants on PPT than on kanamycin. Very few shoots regenerated under the various concentrations of PPT, although buds or shoot primordia developed at a low concentration. We speculated that $C$. metuliferus is very sensitive to PPT. When kanamycin was used for selection at concentrations of 50,150 , and $200 \mathrm{mg} \cdot \mathrm{L}^{-1}$, the survival rates reached $62.1 \%, 89.9 \%$, and $78.1 \%$, respectively (Table 2 ). Based on the high survival rate of $89.9 \%$, kanamycin at $150 \mathrm{mg} \cdot \mathrm{L}^{-1}$ was subsequently used for $C$. metuliferus PI 292190 transformation. In the case of the GUS histochemical assay, the expression of the gus gene was detected only along the margins of leaves and leaf petioles in transformants, indicating that the CaMV $35 \mathrm{~S}$ promoter was preferentially expressed only in certain tissues (Fig. 5). GUS activity driven by the CaMV $35 \mathrm{~S}$ promoter was reported to be very active in vascular bundles and epidermal and parenchyma cells of young leaf petioles and petal and gradually decreases as the tissue matured (Dong et al., 1991).

In conclusion, an efficient (greater than $58 \%$ ) regeneration procedure that only required 3 to 4 weeks to complete was developed and with that transgenic plants of $C$. metuliferus PI 292190 could be obtained in less than 2 months. The transformation rate of C. metuliferus line PI 292190 was reached at $2.5 \%$. This is the first successful attempt for the transformation of any wild Cucumis species.
Abrie, A.L. and J. van Staden. 2001. Development of regeneration protocols for selected cucurbit cultivars. Plant Growth Regulat. 35:263-267.

Adelberg, J. 1998. Regeneration and frequency of tetraploid variants of Cucumis metuliferus are affected by explant induction on semi-solid medium versus the liquid/membrane system. Plant Cell Rep. 17:225-229.

Adelberg, J.W., B.B. Rhodes, H.T. Skorupska, and W.C. Bridges. 1994. Explant origin affects the frequency of tetraploid plants from tissue cultures of melon. HortScience 29:689-692.

Akasaka-Kennedy, Y., K. Tomita, and H. Ezura. 2004. Efficient plant regeneration and Agrobacterium-mediated transformation via somatic embryogenesis in melo (Cucumis melo L.). Plant Sci. 166:763-769.

Beharav, A. and Y. Cohen. 1994. Callus formation from cotyledon and hypocotyls of Cucumis melo L. and C. metuliferus. Cucurbit Genet. Coop. Ret. 17:97-100.

Benzioni, A., S. Mendlinger, and M. Ventura. 1991. Effect of sowing dates, temperatures on germination, flowering, and yield of Cucumis metuliferus. HortScience 26:1051-1053.

Breithaupt, D.E., U. Wirt, and A. Bamedi. 2002. Differentiation between lutein monoester regioisomers and detection of lutein diesters from Marigold flowers (Tagetes erecta $\mathrm{L}$.) and several fruits by liquid chromatography-mass spectrometry. J. Agr. Food Chem. 50:66-70.

Chaturvedi, R. and S.P. Bhatnagar. 2001. Highfrequency shoot regeneration from cotyledon explants of watermelon cv. Sugar Baby. In Vitro Cell. Dev. Biol. Plant 37:255-258.

Chee, P.P. 1991. Plant regeneration from cotyledons of Cucumis melo 'Topmark'. HortScience 26:908-910.

Chee, P.P. and J.L. Slightom. 1992. Transformation of cucumber tissues by microprojectile bombardment: Identification of plants containing functional and non-functional transferred genes. Gene 118:255-260.

Chen, J.F. and J. Adelberg. 2000. Interspecific hybridization in Cucumis-progress, problems, and perspectives. HortScience 35:11-15.

Chen, P.Y., C.K. Wang, S.C. Soong, and K.Y. To. 2003. Complete sequence of the binary vector pBI121 and its application in cloning T-DNA insertion from transgenic plants. Mol. Breed. 11:287-293

Choi, P.S., W.Y. Soh, Y.S. Kim, O.J. Yoo, and J.R Liu. 1994. Genetic transformation and plant regeneration of watermelon using Agrobacterium tumefaciens. Plant Cell Rep. 13:344-348.

Colijn-Hooymans, C.M., J.C. Hakkert, J. Jansen, and J.B.M. Custers. 1994. Competence for regeneration of cucumber cotyledons is restricted to specific developmental stages. Plant Cell Tissue Organ Cult. 39:211-217.

Compton, M.E. and D.J. Gray. 1993. Shoot organogenesis and plant regeneration from cotyledons of diploid triploid and tetraploid watermelon. J. Amer. Soc. Hort. Sci. 118:151-157.

Dong, J.Z., M.Z. Yang, S.R. Jia, and N.H. Chua. 1991. Transformation of melon (Cucumis melo L.) and expression from the cauliflower mosaic virus $35 \mathrm{~S}$ promoter in transgenic melon plants. Nat. Biotechnol. 9:858-863.

Ezura, H., K.I. Yuhashi, T. Yasuta, and K. Minamisawa. 2000. Effect of ethylene on Agrobacterium tumefaciens-mediated gene transfer to melon. Plant Breed. 119:75-79.

Fang, G. and R. Grumet. 1990. Agrobacterium tumefaciens mediated transformation and regeneration of muskmelon plants. Plant Cell Rep. 9:160-164. 
Ficcadenti, N. and G.L. Rotino. 1995. Genotype and medium affect shoot regeneration of melon. Plant Cell Tissue Organ Cult. 40:293-295.

Fulton, T.M., J. Chunwongse, and S.D. Tanksley. 1995. Microprep protocol for extraction of DNA from tomato and other herbaceous plants. Plant Mol. Biol. Rpt. 13:207-209.

Gaba, V., E. Schlarman, C. Elman, O. Sagee, A.A. Watad, and D.J. Gray. 1999. In vitro studies on the anatomy and morphology of bud regeneration in melon cotyledons. In Vitro Cell. Dev. Biol. Plant 35:1-7.

Galperin, M., L. Patlis, A. Ovadia, D. Wolf, A. Zelcer, and D. Kenigsbuch. 2003. A melon genotype with superior competence for regeneration and transformation. Plant Breed. 122: 66-69.

Gonsalves, C., B. Xue, M. Yepes, M. Fuchs, K. Ling, S. Namba, P. Chee, J.L. Slightom, and D. Gonsalves. 1994. Transferring cucumber mosaic virus-white leaf strain coat protein gene into Cucumis melo L. and evaluating transgenic plants for protection against infections. J. Amer. Soc. Hort. Sci. 119:345-355.

Jefferson, R.A. 1987. Assaying chimeric genes in plants: The GUS gene fusion system. Plant Mol. Biol. Rpt. 5:387-405.

Kathiravan, K., G. Vengedesan, S. Singer, B. Steinitz, H.S. Paris, and V. Gaba. 2006. Adventitious regeneration in vitro occurs across a wide spectrum of squash (Cucurbita pepo) genotypes. Plant Cell Tissue Organ Cult. 85: 285-295.

Kristkova, E., A. Lebeda, V. Vinter, and O. Blahousek. 2003. Genetic resources of the genus Cucumis and their morphological description. HortScience 30:14-42.

Lopez-Sese, A.I. and M.L. Gomez-Guillamon. 2000. Resistance to Cucurbit yellowing stunting disorder virus (CYSDV) in Cucumis melo L. HortScience 35:110-113.

McCarthy, W.H., T.C. Wehner, J. Xie, and M.E. Daub. 2001. Improving culture efficiency of Cucumis metuliferus protoplasts. Cucurbit Genet. Coop. Rep. 24:97-101.

Mendlinger, S., A. Benzioni, S. Huyskens, and M. Ventura. 1992. Fruit development and postharvest physiology of Cucumis metuliferus
Mey, a new crop plant. J. Hort. Biotech. Sci. 67: 489-493.

Molina, R.V. and F. Nuez. 1995. Correlated response of in vitro regeneration capacity from different source of explants in Cucumis melo. Plant Cell Rep. 15:129-132.

Motlhanka, D.M.T. 2008. Free radical scavenging activity of selected medicinal plants of Eastern Botswana. Pak. J. Biol. Sci. 11:805-808.

Niedz, R.P., S.S. Smith, K.B. Dunbar, C.T. Stephens, and H.H. Murakishi. 1989. Factors influencing shoot regeneration from cotyledonary explants of Cucumis melo. Plant Cell Tissue Organ Cult. 18:313-319.

Nisini, P.T., G. Colla, E. Granati, O. Temperini, P. Crino, and F. Saccardo. 2002. Rootstock resistance to fusarium wilt and effect on fruit yield and quality of two muskmelon cultivars. Sci. Hort. 93:281-288.

Nugent, P.E. and P.D. Dukes. 1997. Root-knot nematode resistance in Cucumis species. HortScience 32:880-881.

Odhav, B., S. Beekrum, U. Akula, and H. Baijnath. 2007. Preliminary assessment of nutritional value of traditional leafy vegetables in KwaZulu-Natal, South Africa. J. Food Compost. Anal. 20:430-435.

Oridate, T., H. Atsumi, S. Ito, and H. Araki. 1992. Genetic difference in somatic embryogenesis from seeds in melon (Cucumis melo L.). Plant Cell Tissue Organ Cult. 29:27-30.

Pang, S.-Z., F.-J. Jan, D.M. Tricoli, P.F. Russell, K.J. Carney, J.S. Hu, M. Fuchs, H.D. Quemada, and D. Gonsalves. 2000. Resistance to Squash mosaic comovirus in transgenic squash plants expressing its coat protein genes. Mol. Breed. 6:87-93.

Provvidenti, R. and D. Gonsalves. 1982. Resistance to Papaya ringspot virus in Cucumis metuliferus and its relationship to resistance to Watermelon mosaic virus 1. J. Hered. 73:239-240.

Provvidenti, R. and R.W. Robinson. 1974. Resistance to Squash mosaic virus and Watermelon mosaic virus 1 in Cucumis metuliferus. Plant Dis. Reptr. 58:735-738.

Provvidenti, R. and R.W. Robinson. 1977. Inheritance of resistance to Watermelon mosaic virus 1 in Cucumis metuliferus. J. Hered. 68:56-57.
Punja, Z.K., N. Abbas, G.G. Sarmento, and F.A. Tang. 1990. Regeneration of Cucumis sativus var. sativus and $C$. sativus var. hardwickii, $C$. melo, and $C$. metuliferus from explants through somatic embryogenesis and organogenesis. Plant Cell Tissue Organ Cult. 21:93-102.

Raharjo, S.H.T. and Z.K. Punja. 1993. Plantlet regeneration from petiole explants of the African horned cucumber, Cucumis metuliferus. Plant Cell Tissue Organ Cult. 32:169-174.

Romero-Rodriguez, M.A., M.L. Vazquez-Oderiz, J. Lopez-Hernandez, and J. Simal-Lozano. 1992. Physical and analytical characteristics of the kiwano. J. Food Compost. Anal. 5:319 322 .

Schulze, J., C. Balko, B. Zellner, T. Koprek, R. Hansch, A. Nerlich, and R.R. Mendel. 1995. Biolistic transformation of cucumber using embryogenic suspension cultures: Long-term expression of reporter genes. Plant Sci. 112:197206.

Siguenza, C., M. Schochow, T. Turini, and A. Ploeg. 2005. Use of Cucumis metuliferus as a rootstock for melon to manage Meloidogyne incognita. J. Nematol. 37:276-280.

Tang, F.A. and Z.K. Punja. 1989. Isolation and culture of protoplasts of Cucumis sativus and Cucumis metuliferus and methods for their fusion. Cucurbit Genet. Coop. Rpt. 12:29-32.

Vasudevan, A., N. Selvaraj, A. Ganapathi, and C.W. Choi. 2007. Agrobacterium-mediated genetic transformation in cucumber (Cucumis sativus L.). Amer. J. Biotechnol. Biochem. 3:24-32.

Vengadesan, G., R.P. Anand, N. Selvaraj, R. PerlTreves, and A. Ganapathi. 2005. Transfer and expression of nptII and bar genes in cucumber (Cucumis sativus L.). In Vitro Cell. Dev. Biol. Plant 41:17-21.

Wannang, N.N., N.S. Jimam, S. Omale, M.L.P. Dapar, S.S. Gyang, and J.C. Aguiyi. 2007 Effects of Cucumis metuliferus (Cucurbitaceae) fruits on enzymes and haematological parameters in albino rats. Afr. J. Biotechnol. 6:2515-2518.

Wehner, T.C., S.A. Walters, and K.R. Barker. 1991. Resistance to root-knot nematodes in cucumber and horned cucumber. Suppl. J. Nematol. 23:611-614. 